\title{
Pengukuran Nilai CT Number Pada Phantom CIRS 062m Sebagai Data Input Kalkulasi Dosis Program ISIS 3d Di Treatment Planning System
}

\author{
Purwantiningsi ${ }^{1}$, Hadi Lesmana ${ }^{1}$ \\ ${ }^{1}$ Jurusan Fisika, Fakultas Teknik dan Sains, Universitas Nasional, Jakarta \\ Email: purwanti.ningsih85@yahoo.co.id
}

\begin{abstract}
Abstrak. Telah dilakukan pengukuran nilai CT number pada pesawat CT Scan Simulator General Elektrik di RSPAD Gatot Soebroto Jakarta dengan menggunakan phanthom CIRS 062 dengan berbagai variasi nilai jaringan ( lung inhale, lung exhale, adipose, breast, water, muscle, liver, bone 200, bone 800 ), dilakukan scanning phantom dengan ketebalan slices $10 \mathrm{~mm}, \mathrm{kV}$ 100, mAs 190. Pengukuran CT number dilakukan dengan memberi tanda lingkaran pada setiap objek jaringan dengan diameter lingkaran Region Of Interest (ROI) yang sama, maka didapatkan hasil CT number ( Lung inhale ; -800.9, Lung exhale ; -492.1, Adipose ; -66.8, Breast ; -30.2, Water ; -7.7, Muscle ; 47.5, Liver ; 56.2, Bone 200 ; 255.3, bone $800 ; 929$ ). Hasil nilai pengukuran CT number jaringan di input kedalam program iSis 3D yang terdapat di TPS (Treatment Planning Sistem). Hasil kalkulasi dosis dilakukan menggunakan sampel planning pada organ paru pada program iSis 3D dengan menggunakan energi elektron $8 \mathrm{MeV}$ dan didapatkan hasil perbedaan sebelum dan sesudah dimasukan nilai densitas elektron dalam kurva DVH (dose volume histogram). hasil yang didapat dari bacaan kurva DVH antara sebelum dan sesudah dimasukan nilai densitas menyatakan bahwa selisih perbedaan pada daerah jaringan paru sebelah kanan akumulasi dosis rata-rata (Dmean) $3.6 \%$ pada volume $2080 \mathrm{~cm} 3$, pada daerah jaringan paru sebelah kiri dosis rata-rata (Dmean) 2.4\% pada volume $1271 \mathrm{~cm} 3$, dan pada organ jantung dosis rata-rata (Dmean) 1,36\% pada volume 199,4 $\mathrm{cm} 3$.
\end{abstract}

Kata kunci : CT number, Densitas Elektron, kurva DVH

\begin{abstract}
Have done the measurement value of ct number on ct scan simulator general electric at RSPAD Gatot Soebroto Jakarta using phanthom CIRS 062 with variety of special value of lung tissue (inhale, lung exhale, adipose, breast, water, muscle, liver, bone 200, bone 800), has done scanning the phantom with a thickness of $10 \mathrm{~mm}$ slices, $100 \mathrm{kV}$, mAs 190. Measurement of CT number performed by a circle on each network object with a diameter of circle Region Of Interest (ROI) is the same, the obtained results of CT number ( lung inhale; -800.9, lung exhale; -492.1, adipose; -66.8, breast; -30.2, water; -7.7, muscle; 47.5, liver; 56.2, bone 200; 255.3, bone 800; 929 ). He value of CT measurement of the number of input into the program's network of iSis in 3D TPS (Treatment Planning systems). Dose calculation results carried out using a sample planning on pulmonary organs in $3 D$ with the iSis program using electron energy $8 \mathrm{MeV}$ and the obtained results the difference before and after the entered value of the density of electrons within the curve of the DVH (dose-volume histogram). The results gained from the reading curve DVH between before and after the entered value of the density that difference in pulmonary tissue area to the right of the average accumulation of doses (Dmean) 3.6\% on a volume of $2080 \mathrm{~cm} 3$, pulmonary tissue area on the left of the average dose (Dmean) $2.4 \%$ on an volume $1271 \mathrm{~cm} 3$, and in the organ the heart of average dose (Dmean) $1.36 \%$ on volume $199,4 \mathrm{~cm} 3$.
\end{abstract}

Keywords: Electron Density, CT number, DVH curve.

\section{PENDAHULUAN}

Radioterapi adalah salah satu pengobatan untuk penyakit kanker dimana dengan pemberian radiasi pada kanker sangat efektif pada saat ini. Pemberian dosis radiasi yang tepat pada volume target semaksimal mungkin, serta mengurangi dosis pada jaringan atau organ kritis seminimal mungkin merupakan cara pemberian pengobatan secara 3-dimensi (3-D CRT) dalam teknik radioterapi yang sudah digunakan di Indonesia. Teknik 3-D CRT (Three Dimension Conformal 
Reconstruction Technique) merupakan salah satu teknik cara pengobatan radiasi yang berdasarkan posisi, ukuran dan bentuk target radiasi. Modalitas pendukung untuk pengobatan 3 dimensi perlu adanya immobilisasi (fiksasi pasien), CT-planning (pemberi informasi anatomi organ), dan simulator (simulasi pasien berdasarkan planning/CT-plan-anatomi tulang). Metode radiasi ini termasuk pengobatan yang non-invasif, juga pengobatan lanjut dari pasca-operatif tumor.

Kegiatan radioterapi pada saat sekarang telah menggunakan pemberian dosis tinggi. dengan berkembangnya teknologi, informasi anatomi yang digunakan untuk keperluan terapi telah dapat dipenuhi untuk keperluan perencanaan terapi kanker sebelum pasien diberikan perawatan radioterapi. Semua data anatomi tersebut akan digunakan untuk perhitungan dosis oleh TPS (Treatment Planning System). Dalam aplikasinya diharapkan kesalahan perhitungan TPS tidak melebihi apa yang direkomendasikan oleh ICRU dari -5 sampai $+7 \%$, untuk mencapai persyaratan tersebut perlu dilakukan serangkaian pengujian terhadap semua sistem yang terlibat dalam proses radioterapi. Salah satu komponen penting dalam proses radioterapi pasien yaitu TPS, TPS berfungsi untuk melakukan simulasi perhitungan dosis, ketelitian perhitungan sangat penting dalam pemberian dosis kepada pasien. Kesesuaian masing - masing parameter merupakan suatu keharusan, sedikit kesalahan terhadap salah satu parameter akan mengakibatkan kesalahan pemberian dosis kepada pasien dan upaya terapi akan gagal mencapai tujuannya.

Data yang digunakan TPS untuk melakukan perhitungan adalah data eksperimen, data tersebut disesuaikan dengan perhitungan pada kondisi standar yang telah ditentukan oleh manual software yang bersangkutan, dalam hal ini TPS iSis 3D. Sebelum digunakan suatu Treatment Planning System harus di uji kebenarannya, untuk tujuan itu maka sangat perlu dilakukan pengukuran nilai densitas elektron pada CT planning dengan menggunakan phantom CIRS Model 062M Electron density sebagai acuan dari kalkulasi dosis pada program iSis 3D.

\section{METODE DAN BAHAN}

Penelitian ini dilakukan dengan menggunakan pesawat CT Simulator Planning dibagian Instalasi Radioterapi RSPAD Gatot Soebroto. Pada CT scanner mempunyai koefisien atenuasi linear yang mutlak dari suatu jaringan yang diamati, yaitu berupa CT Number. Tulang memiliki nilai besaran CT Number yang tertinggi yaitu sebesar $1000 \mathrm{HU}$ (Hounsfield Unit), dan udara mempunyai nilai CT Number yang terendah yaitu -1000 HU (Hounsfield Unit), sedangkan sebagai standar digunakan air yang memiliki CT Number 0 HU (Hounsfield Unit). Nilai diatas merupakan nilai pada pesawat CT yang memiliki faktor pembesaran konstan 1000, untuk memperjelas suatu struktur yang satu dengan struktur yang lainnya yang mempun yai nilai perbedaan koefisien atenuasi kurang dari 10\% maka dapat digunakan window width untuk memperoleh rentang yang lebih luas.

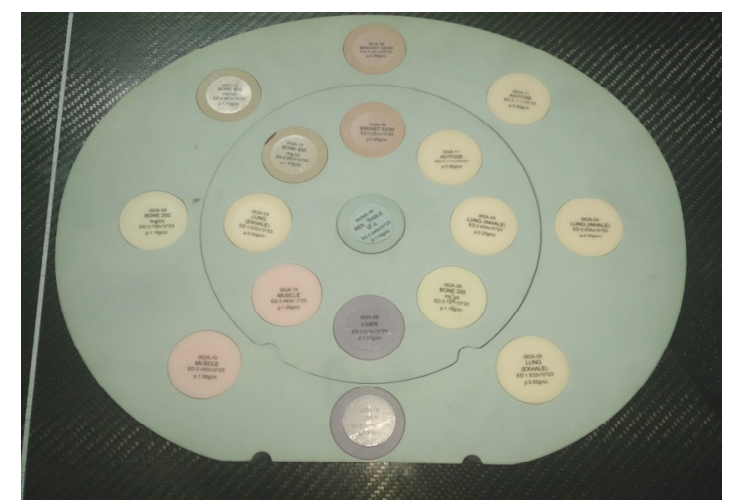

GAMBAR 1. Phantom CIRS 062M Electron density.Dokumentasi Pribadi

CT scan digunakan untuk mengoreksi inhomogeneities jaringan dalam perencanaan pengobatan radioterapi maka sangat penting untuk mendapatkan hubungan yang tepat antara CT Number 
(dalam satuan Housfield) dan densitas elektron. Model 062M Elektron Density phantom memungkinkan korelasi yang tepat dari data CT dengan densitas elektron dari berbagai jaringan seperti gambar 1. Phantom ini diproduksi dari CIRS Setara Bahan Jaringan .

Phantom CIRS Model 062M terdiri dari disk yang terpasang terbuat dari plastik air . Terdiri dari delapan jaringan yang berbeda dan dapat diposisikan di 17 lokasi yang berbeda dalam bidang scan. Termasuk adalah memasukkan jarum suntik yang dapat diisi dengan bahan cairan atau padat.

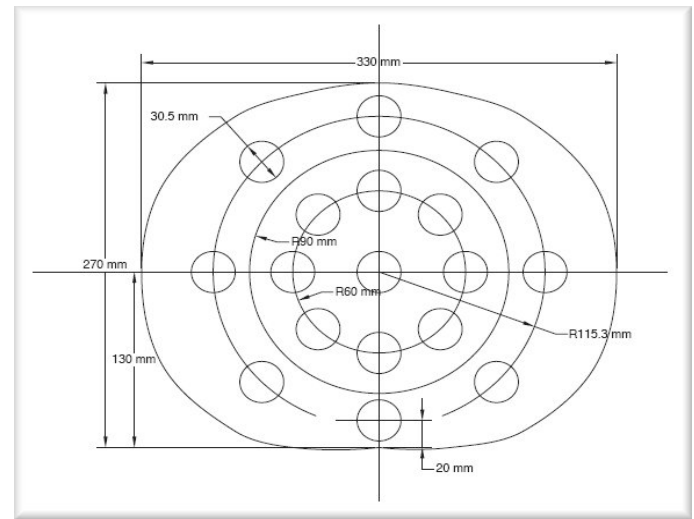

GAMBAR 2. Dimensi CIRS Model 062M [7].

Gambar 2 diatas merupakan keseluruhan dimensi Phantom CIRS 062 yaitu $25 \mathrm{~cm}$ x $33 \mathrm{~cm}$ x 27 $\mathrm{cm}$, Berat : $40 \mathrm{lbs}$, material phantom body plastic water - DT, Insert CIRS Tissue Equivalent Materials (epoxy resin based).

TABEL 1. Data Phantom CIRS Model 062M Electron density

\begin{tabular}{|c|c|c|c|}
\hline No. & $\begin{array}{c}\text { Material / } \\
\text { Jaringan }\end{array}$ & $\begin{array}{c}\text { Masa jenis } \\
\boldsymbol{\rho}(\mathbf{g} / \mathbf{c c})\end{array}$ & $\begin{array}{c}\text { Densitas } \\
\text { Elektron relatif }\end{array}$ \\
\hline 1 & Lung Inhale & 0,2 & $0,634 \times 10^{23}$ \\
\hline 2 & Lung Exhale & 0,5 & $1,632 \times 10^{23}$ \\
\hline 3 & Adipose & 0,96 & $3,171 \times 10^{23}$ \\
\hline 4 & Breast & 0,99 & $3,261 \times 10^{23}$ \\
\hline 5 & Water & 1 & $3,340 \times 10^{23}$ \\
\hline 6 & Muscle & 1,06 & $3,483 \times 10^{23}$ \\
\hline 7 & Liver & 1,07 & $3,516 \times 10^{23}$ \\
\hline 8 & Bone 200 & 1,16 & $3,73 \times 10^{23}$ \\
\hline 9 & Bone 800 & 1,53 & $4,862 \times 10^{23}$ \\
\hline
\end{tabular}

Treatment Planning System atau dapat pula disebut dengan sistem perencanaan radiasi merupakan suatu proses yang sistematik dalam membuat rencana strategi terapi radiasi, meliputi sekumpulan instruksi dari prosedur radioterapi dan mengandung deskripsi fisik, serta distribusi dosis berdasar pada informasi geometrik atau topografi yang ada pada pencitraan (imajing) agar terapi radiasi dapat diberikan secara tepat. TPS ini dalam tampilannya bisa 2D bisa juga 3D.

Tujuan sistem perencanaan radiasi $2 \mathrm{D}$ dan 3D adalah untuk menyesuaikan dosis pada volume target dan mengurangi dosis untuk jaringan normal atau organ beresiko yang ada disekitarnya. Hal ini meliputi : a). Posisi pasien terapi b). Imobilisasi c). Mengumpulkan data pencitraan pasien c). Menetapkan volume target dan organ - organ beresiko berdasarkan kumpulan data bentuk - bentuk sinar yang didesain secara grafis dan orientasi sinar; d). Bentuk lapangan yang dipilih menggunakan BEV; e). Distribusi dosis 3 dimensi; f). Kalkulasi menggunakan algoritma tiga dimensi dan perbandingan informasi yang didapat dari Histogram Dosis Volume (DHV).

Untuk mengetahui nilai CT number dari setiap jaringan pada phantom maka dibuat dengan melakukan pencitraan imajing CT scanning pada phantom CIRS di Instalasi Radioterapi RSPAD Gatot Soebroto. Gambaran hasil scanning phantom di ukur dengan menggunakan tools 
ROI (region of interest) dari setiap densitas jaringan dengan besaran diameter yang sama maka akan terlihat nilai $\mathrm{HU}$ pada gambarannya.

Untuk keperluan kalkulasi dosis, nilai CT number dari setiap jaringan pada phantom yang telah di ukur kemudian dimasukan kedalam program iSis 3D di TPS (treatment planning system). Untuk mengetahui perbedaan hasil input nilai CT number dari setiap jaringan maka dilakukan perencaan radiasi dengan melakukan kalkulasi dosis pada organ yang akan di sinar, dalam hal ini penulis mengambil sample pada organ paru yang memiliki inhomogenitas jaringan yang banyak. hasil kalkulasi dosis akan terlihat perbedaan antara sebelum dimasukan nilai CT number dan yang sesudah.

\section{HASIL DAN PEMBAHASAN}

Dari hasil pengukuran phantom CIRS model 062 Elektron Density dengan melakukan pencitraan imajing pada CT Scan Simulator GE di RSPAD Gatot Soebroto pada gambar 3, maka didapat nilai CT number dalam satuan HU (hounstfield unit) dari setiap jaringan yang tercantum dalam lampiran tabel 2, pada tabel tersebut berisikan jenis material ( jaringan), massa jenis atau kerapatan jaringan $\rho(\mathrm{g} / \mathrm{cc})$, Densitas Elektron relatif dan nilai $\mathrm{CT}$ number hasil pengukuran . Dari 8 jenis material atau jaringan yang berbeda di ukur 2 jenis jaringan yang setara sebagai bahan pembanding nilai CT number setiap jaringan.

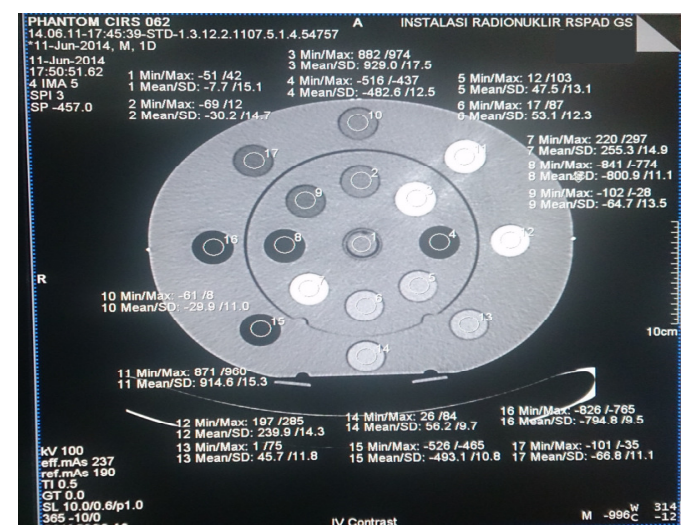

GAMBAR 3. Hasil pencitraan Phantom CIRS 062 pada CT Simulator.

TABEL 2. Hasil pengukuran nilai CT number pada Phantom CIRS

\begin{tabular}{|c|c|c|c|c|}
\hline \multirow{2}{*}{ No } & \multirow{2}{*}{$\begin{array}{c}\text { Material / } \\
\text { Jaringan }\end{array}$} & $\begin{array}{c}\text { Massa } \\
\text { Jenis } \\
\mathbf{\rho}\left(\mathbf{g} / \mathbf{c m}^{3}\right)\end{array}$ & \multicolumn{2}{|c|}{$\begin{array}{c}\text { CT Number (HU) } \\
\text { Hasil Pengukuran }\end{array}$} \\
\cline { 4 - 5 } & & & $\begin{array}{c}\text { Bagian } \\
\text { Dalam }\end{array}$ & Bagian Luar \\
\hline 1 & Lung Inhale & 0,2 & $\mathbf{- 8 0 0 , 9}$ & $-794,8$ \\
\hline 2 & Lung Exhale & 0,5 & $-482,6$ & $\mathbf{- 4 9 2 , 1}$ \\
\hline 3 & Adipose & 0,96 & $-64,7$ & $\mathbf{- 6 6 , 8}$ \\
\hline 4 & Breast & 0,99 & $\mathbf{- 3 0 , 2}$ & $-29,9$ \\
\hline 5 & Water & 1 & $\mathbf{- 7 , 7}$ & - \\
\hline 6 & Muscle & 1,06 & $\mathbf{4 7 , 5}$ & 45,7 \\
\hline 7 & Liver & 1,07 & 53,1 & $\mathbf{5 6 , 2}$ \\
\hline 8 & Bone 200 & 1,16 & $\mathbf{2 5 5 , 3}$ & 239,9 \\
\hline 9 & Bone 800 & 1,53 & $\mathbf{9 2 9}$ & 914,6 \\
\hline
\end{tabular}

Setelah semua data sudah dimasukan dan di save maka untuk melihat hasil dari input nilai CT number yang baru perlu dilakukannya simulasi planning untuk mendapatkan hasil kurva isodose, dalam penelitian ini penulis melampirkan sampel perbandingan simulasi planning antara yang sebelum dan sesudah di masukan nilai CT number dan relatif densitas elektron, 
simulasi ini dilakukan dengan sampel pada organ paru dengan menggunakan energi elektron 8 $\mathrm{MeV}$ dan $10 \mathrm{MeV}$ dengan luas lapangan applikator $10 \times 10 \mathrm{~cm}$ pada arah penyinara PA.

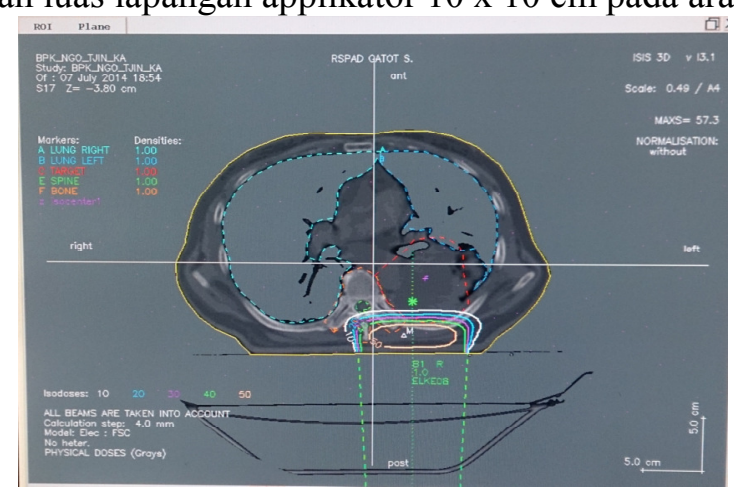

GAMBAR 4. Simulasi planning kurva isodoe sebelum di masukan nilai CT number dan densitas elektron (dengan menggunakan energi $8 \mathrm{MeV}$ )

Pada gambar 4 dapat dilihat salah satu simulasi planning pada objek paru dengan arah sinar (garis putus -putus hijau) dari bawah menuju ke atas (PA) pada densitas yang belum dilakukan pengukuran, maka sangat jelas terlihat prosentase dosis yang mengenai objek lebih luas dikarenakan tidak adanya hambatan yang berbeda dari setiap jaringan, pada gambar kurva isodose dapat di lihat bahwa prosentase dosis maximum hanya $50 \%$ (garis kuning), 40\% (garis hijaun), 30\% (garis ungu), 20\% (garis biru muda), 10\% (garis putih).

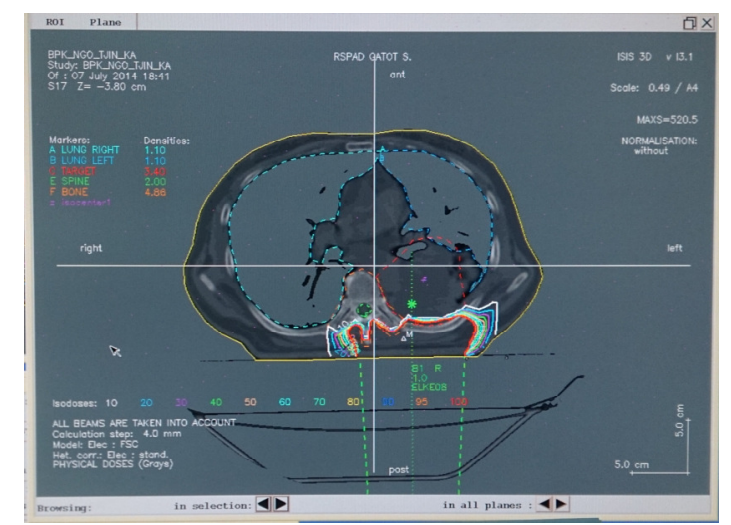

GAMBAR 5. Simulasi planning kurva isodoe sesudah di masukan nilai CT number dan densitas elektron (dengan menggunakan energi $8 \mathrm{MeV}$ )

Pada Gambar 5. Dapat dilihat salah satu simulasi planning pada objek paru dengan arah sinar (garis putus -putus hijau) dari bawah menuju ke atas (PA) pada densitas yang sudah dilakukan pengukuran, maka sangat jelas terlihat perbedaan prosentase dosis antaran gambar 4 dan 5, pada gambar 5 kurva isodose yang mengenai objek lebih rapat dikarenakan adanya hambatan yang berbeda dari setiap jaringan. 


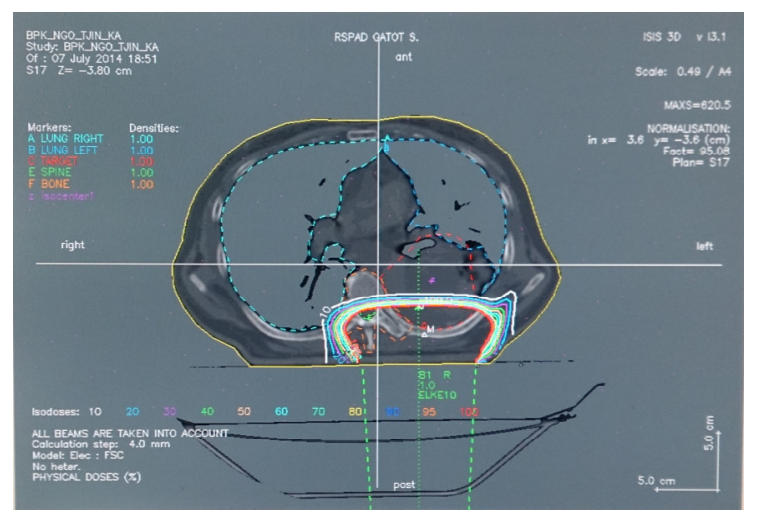

GAMBAR 6. Simulasi planning kurva isodoe sebelum di masukan nilai CT number dan densitas elektron (dengan menggunakan energi $10 \mathrm{MeV}$ )

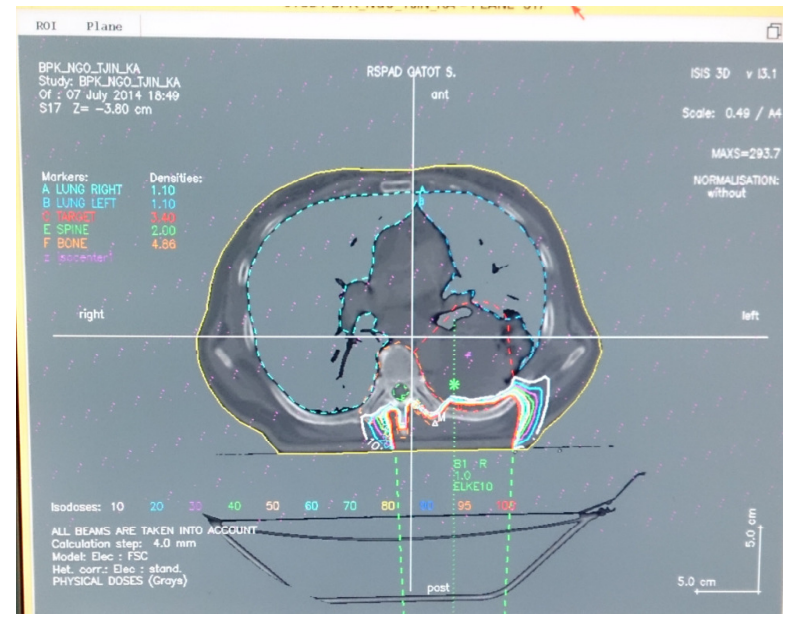

GAMBAR 7. Simulasi planning kurva isodoe sesudah di masukan nilai CT number dan densitas elektron (dengan menggunakan energi $10 \mathrm{MeV}$ )

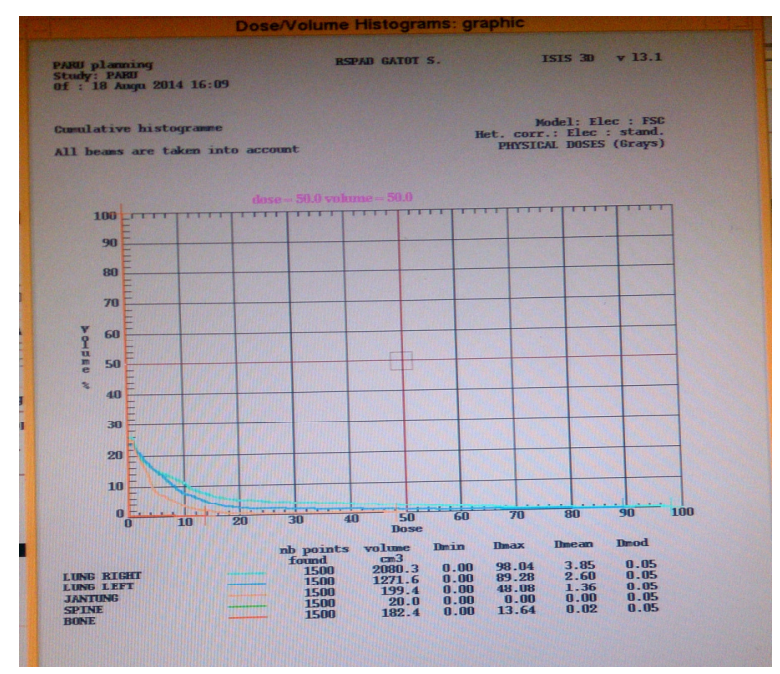

GAMBAR 8. Kurva DVH sebelum di masukan nilai CT number dan densitas elektron (dengan menggunakan energi $10 \mathrm{MeV})$

Dari Gambar 8 kurva DVH (dose volume histrogram) dinyatakan bahwa pada daerah jaringan paru sebelah kanan akumulasi dosis maximum (Dmax) menerima 98,04\% dan dosis rata-rata (Dmean) $3,85 \%$ pada volume $2080 \mathrm{~cm} 3$, pada daerah jaringan paru sebelah kiri dosis maximum (Dmax) menerima 89,28\% dan dosis rata-rata (Dmean) 2,60\% pada volume $1271 \mathrm{~cm} 3$, dan pada organ jantung dosis maximum (Dmax) menerima 48,08\% dan dosis rata-rata (Dmean) $1,36 \%$ pada volume $199,4 \mathrm{~cm}^{3}$. 


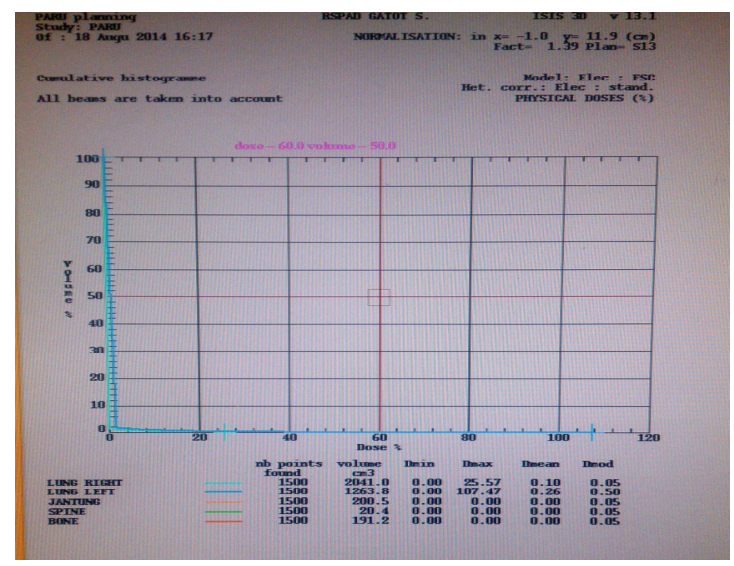

GAMBAR 9. Kurva DVH sesudah di masukan nilai CT number dan densitas elektron (dengan menggunakan energi $10 \mathrm{MeV}$ )

Dari Gambar 9 kurva DVH (dose volume histrogram) dinyatakan bahwa pada daerah jaringan paru sebelah kanan akumulasi dosis maximum (Dmax) menerima 25,57\% dan dosis rata-rata (Dmean) $0,10 \%$ pada volume $2041 \mathrm{~cm} 3$, pada daerah jaringan paru sebelah kiri dosis maximum (Dmax) menerima 107\% dan dosis rata-rata (Dmean) 0,26\% pada volume $1263 \mathrm{~cm}^{3}$, dan pada organ jantung dosis maximum (Dmax) menerima 0\% dan dosis rata-rata (Dmean) $0 \%$ pada volume $20,4 \mathrm{~cm}^{3}$.

Dalam penelitian yang dilakukan pada Instalasi Radioterapi Rumah Sakit Pusat Angkatan Darat Gatot Subroto, dengan scanning phantom CIRS 062 Electron Density untuk mendapatkan nilai densitas elektron pada tiap-tiap organ sebagai bahan perhitungan dan acuan pada TPS, didapatkan nilai CT number pada tiap-tiap densitas organ yang dapat dilihat pada tabel 3 .

TABEL 3. Hasil pengukuran nilai CT number pada Phantom CIRS model $062 \mathrm{M}$ Density Elektron.

\begin{tabular}{|c|c|c|c|c|}
\hline \multirow{2}{*}{ No } & \multirow{2}{*}{$\begin{array}{c}\text { Material / } \\
\text { Jaringan }\end{array}$} & \multirow{2}{*}{$\begin{array}{c}\text { Massa Jenis } \\
\boldsymbol{\rho}\left(\mathbf{g} / \mathbf{c m}^{3}\right)\end{array}$} & \multicolumn{2}{|c|}{$\begin{array}{c}\text { CT Number (HU) } \\
\text { Hasil Pengukuran }\end{array}$} \\
\cline { 4 - 5 } & & & \multicolumn{2}{|c|}{$\mathbf{k V p ~ 1 0 0}$} \\
\cline { 4 - 5 } & & 0,2 & $-800,9$ & Bagian Luar \\
\hline 1 & Lung Inhale & 0,5 & $-482,6$ & $-794,8$ \\
\hline 2 & Lung Exhale & $\mathbf{- 4 9 2 , 1}$ \\
\hline 3 & Adipose & 0,96 & $-64,7$ & $\mathbf{- 6 6 , 8}$ \\
\hline 4 & Breast & 0,99 & $\mathbf{- 3 0 , 2}$ & $-29,9$ \\
\hline 5 & Water & 1 & $\mathbf{- 7 , 7}$ & - \\
\hline 6 & Muscle & 1,06 & $\mathbf{4 7 , 5}$ & 45,7 \\
\hline 7 & Liver & 1,07 & 53,1 & $\mathbf{5 6 , 2}$ \\
\hline 8 & Bone 200 & 1,16 & $\mathbf{2 5 5 , 3}$ & 239,9 \\
\hline 9 & Bone 800 & 1,53 & $\mathbf{9 2 9}$ & 914,6 \\
\hline
\end{tabular}

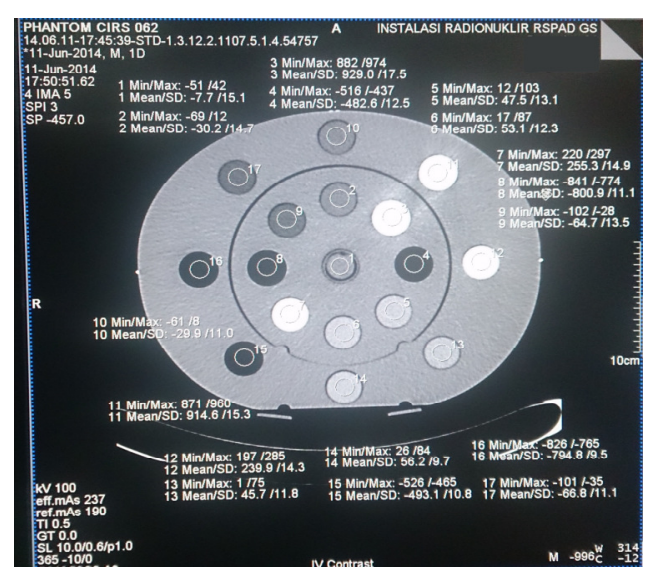

GAMBAR 10 . Hasil pencitraan Phantom CIRS 062 pada CT Simulator dan pengukuran CT number dengan ROI (region of interest) pada setiap jaringan. 
Pada gambar 10 dapat dilihat hasil scanning pada phantom CIRS berupa pencitraan gambaran dalam setiap slice, dilakukan scanning potongan axial pada CT Simulator dengan kV 100 dan ref mAs 190 pada thicknes $5 \mathrm{~mm}$. Phantom diletakan di atas meja pemeriksaan dengan posisi berdiri dengan penyanggah, kemudian dilakukan pemberian tanda atau marker pada bagian tengah dari phantom tersebut dengan menggunakan timah. setelah dilakukan scanning maka hasil gambaran akan terlihat dalam potongan axial yang akan diambil satu slice bagian tengah dari phantom tersebut yang sejajar dengan marker yang terlihat pada potongan untuk mendapatkan kualitas dari setiap kontur jaringan pada phantom terlihat meyeluruh.

Untuk pengukuran nilai HU (hounsfield unit) atau CT number maka dilakukan dengan memberi tanda lingkaran pada aplikasi ROI(region of interest), pemberian tanda lingkaran dilakukan pada tiap - tiap jaringan yang terlihat pada gambaran, diameter lingkaran masing - masing jaringan harus sama dengan ukuran tidak melebihi batas lingkaran dari kontur jaringan tersebut. Setelah pemberian tanda lingkaran dengan aplikasi ROI (region of interest) pada tiap - tiap jaringan maka secara otomatis nilai CT number akan muncul sesuai dengan lingkaran lingkaran pada jaringan yang di beri tanda.

Dari hasil 3, tidak terlihat perbedaan yang begitu jauh nilai CT number dari jaringan yang sama antara bagian dalam dan luar pada phantom. Tetapi pada jaringan yang berbeda memiliki nilai $C T$ number yang berbeda, pengaruh nilai $C T$ number berdasarkan nilai massa jenis dari setiap jaringan, dalam tabel menunjukan bahwa jaringan yang memiliki nilai massa jenis yang rendah maka nilai $C T$ numbernya pun memiliki nilai yang rendah atau minus dan sebaliknya jika jaringan memiliki nilai massa jenis atau kepadatan yang tinggi maka nilai $C T$ numbernya pun akan tinggi atau plus.

Sebelum dilakukannya input nilai densitas pada setiap organ, densitas organ sebelumnya dalam program iSis 3D disama ratakan dengan nilai 1 terhadap semua jaringan dimana untuk densitas seperti tulang, paru, liver, lemak, otot dan dada diberi nilai 1. Namun setelah pengukuran dengan menggunakan phantom CIRS 062 didapatkan hasil yang tertera dalam tabel 4.

TABEL 4. Daftar nilai yang akan di input kedalam program iSis.

\begin{tabular}{|c|c|c|c|c|}
\hline No. & $\begin{array}{c}\text { Material / } \\
\text { Jaringan }\end{array}$ & $\begin{array}{c}\text { Densitas / masa } \\
\text { jenis } \\
\mathbf{p}(\mathbf{g} / \mathbf{c c})\end{array}$ & $\begin{array}{c}\text { Densitas Elektron } \\
\text { Referensi }\end{array}$ & $\begin{array}{c}\text { CT Number Hasil } \\
\text { Pengukuran }\end{array}$ \\
\hline 1 & Lung Inhale & 0,2 & $0,634 \times 10^{23}$ & $-800,9$ \\
\hline 2 & Lung Exhale & 0,5 & $1,632 \times 10^{23}$ & $-492,1$ \\
\hline 3 & Adipose & 0,96 & $3,171 \times 10^{23}$ & $-66,8$ \\
\hline 4 & Breast & 0,99 & $3,261 \times 10^{23}$ & $-30,2$ \\
\hline 5 & Water & 1 & $3,340 \times 10^{23}$ & $-7,7$ \\
\hline 6 & Muscle & 1,06 & $3,483 \times 10^{23}$ & 47,5 \\
\hline 7 & Liver & 1,07 & $3,516 \times 10^{23}$ & 56,2 \\
\hline 8 & Bone 200 & 1,16 & $3,73 \times 10^{23}$ & 255,3 \\
\hline 9 & Bone 800 & 1,53 & $4,862 \times 10^{23}$ & 929 \\
\hline
\end{tabular}

Untuk melihat hasil perbandingan maka perlu dilakukannya simulasi planning pada program iSis $3 \mathrm{D}$, dalam hal ini penulis mengambil contoh planning dengan menggunakan objek paru yang memiliki banyak perbedaan jumlah densitas jaringan, simulasi dilakukan dengan menggunakan energi elektron $8 \mathrm{MeV}$ dan $10 \mathrm{MeV}$ pada teknik penyinaran PA (postero anterior) dengan applikator $10 \times 10 \mathrm{~cm}$ dengan dosis fraksinasi $1 \mathrm{~Gy}$, simulasi dibuat antara sebelum dilakukannya input nilai densitas elektron dan sesudah dimasukan nilai densitas elektron.

Densitas yang berbeda dari tiap-tiap bahan akan menyebabkan perbedaan intensitas yang akan mengenai target, dan dengan memperhitungkannya dengan tepat maka dapat meminimalisir dosis organ sehat di sekitarnya. Kurva DVH (dose volume histrogram) pada energi $8 \mathrm{MeV}$ dinyatakan bahwa pada daerah jaringan paru sebelah kanan akumulasi dosis maximum (Dmax) menerima 98,04\% dan dosis rata-rata (Dmean) 3,85\% pada volume $2080 \mathrm{~cm} 3$, pada daerah jaringan paru sebelah kiri dosis maximum (Dmax) menerima 89,28\% dan dosis rata-rata 
(Dmean) 2,60\% pada volume $71 \mathrm{~cm} 3$, dan pada organ jantung dosis maximum (Dmax) menerima 48,08\% dan dosis rata-rata (Dmean) 1,36\% pada volume 199,4 cm3.

Kurva DVH (dose volume histrogram) pada energi $10 \mathrm{MeV}$ dinyatakan bahwa pada daerah jaringan paru sebelah kanan akumulasi dosis maximum (Dmax) menerima 25,57\% dan dosis rata-rata (Dmean) $0,10 \%$ pada volume $2041 \mathrm{~cm} 3$, pada daerah jaringan paru sebelah kiri dosis maximum (Dmax) menerima 107\% dan dosis rata-rata (Dmean) 0,26\% pada volume $1263 \mathrm{~cm} 3$, dan pada organ jantung dosis maximum (Dmax) menerima 0\% dan dosis rata-rata (Dmean) 0\% pada volume $20,4 \mathrm{~cm} 3$.

\section{KESIMPULAN}

Telah dilakukan penelitian pengukuran nilai CT number sebagai kalkulasi dosis pada program isis 3D menggunakan Phantom CIRS 062 dengan melakukan pencitraan CT Simulator di radioterapi. Nilai hasil pengukuran berupa CT number dari setiap jaringan pada phantom di input kedalam program isis 3D sehingga menghasilkan nilai prosentase pada kurva isodose yang lebih akurat karena adanya perbedaan nilai dari tiap - tiap jaringan. Kurva DVH (dose volume histrogram) pada energi $8 \mathrm{MeV}$ dinyatakan bahwa pada daerah jaringan paru sebelah kanan akumulasi dosis maximum (Dmax) menerima 98,04\% dan dosis rata-rata (Dmean) 3,85\% pada volume $2080 \mathrm{~cm} 3$, pada daerah jaringan paru sebelah kiri dosis maximum (Dmax) menerima $89,28 \%$ dan dosis rata-rata (Dmean) 2,60\% pada volume $1271 \mathrm{~cm} 3$, dan pada organ jantung dosis maximum (Dmax) menerima 48,08\% dan dosis rata-rata (Dmean) 1,36\% pada volume 199,4 cm3. Kurva DVH (dose volume histrogram) pada energi $10 \mathrm{MeV}$ dinyatakan bahwa pada daerah jaringan paru sebelah kanan akumulasi dosis maximum (Dmax) menerima 25,57\% dan dosis rata-rata (Dmean) 0,10\% pada volume $2041 \mathrm{~cm} 3$, pada daerah jaringan paru sebelah kiri dosis maximum (Dmax) menerima 107\% dan dosis rata-rata (Dmean) 0,26\% pada volume 1263 $\mathrm{cm} 3$, dan pada organ jantung dosis maximum (Dmax) menerima $0 \%$ dan dosis rata-rata (Dmean) $0 \%$ pada volume $20,4 \mathrm{~cm}^{3}$.

\section{DAFTAR PUSTAKA}

[1] Shusterman, A.J, Shusterman, G.P (1977). Teaching Chemistry with Elektron Density Models, The Journal of Chemical Education.

[2] Podgorsak, E.B. (2003). IAEA publishing Review Radiation Oncology Physics

[3] IAEA-TECDOC-1583 Commissioning of Radiotherapy Treatment Planning Systems, Testing for Typical External Beam Treatment Techniques

[4] John, H.E, Cunningham, J.R., Charles C thomas (1983) The Physics of Radiology 4th Edition Publisher.

[5] AAPM Radiation Therapy Quality assurance for computed tomography simulator and the computed tomography simulation process : Report of the Comitte No. 66, American Association of Physicists in Medicine. 2003

[6] Sprawls, P. Jr., "Physical Principles of Medical Imaging", second edition, Aspen Publisher, USA, 1995

[7] www.cirsinc.com, 3 Maret 2014. 